\title{
Correction to: The role of self-reference and personal goals in the formation of memories of the future
}

\section{Olivier Jeunehomme ${ }^{1} \cdot$ Arnaud D'Argembeau $^{1}$}

Published online: 15 March 2021

(C) The Psychonomic Society, Inc. 2021

\section{Correction to: Memory \& Cognition} https://doi.org/10.3758/s13421-021-01150-9

The values for Personal goals were placed alongside the column headings instead of under the column headings in Table 8 in this article as originally published.

The original article has been corrected.

Publisher's note Springer Nature remains neutral with regard to jurisdictional claims in published maps and institutional affiliations.

The online version of the original article can be found at https://doi.org/ 10.3758/s13421-021-01150-9

\section{Olivier Jeunehomme}

o.jeunehomme@uliege.be

1 Department of Psychology, Psychology and Neuroscience of Cognition Research Unit, University of Liège, Place des Orateurs 1 (B33), 4000 Liège, Belgium 